ח

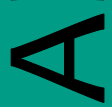

n

Ш

Z

O

$\underline{-}$

$F$

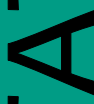

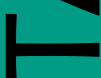

ه

Ш

n

n

$\overline{0}$
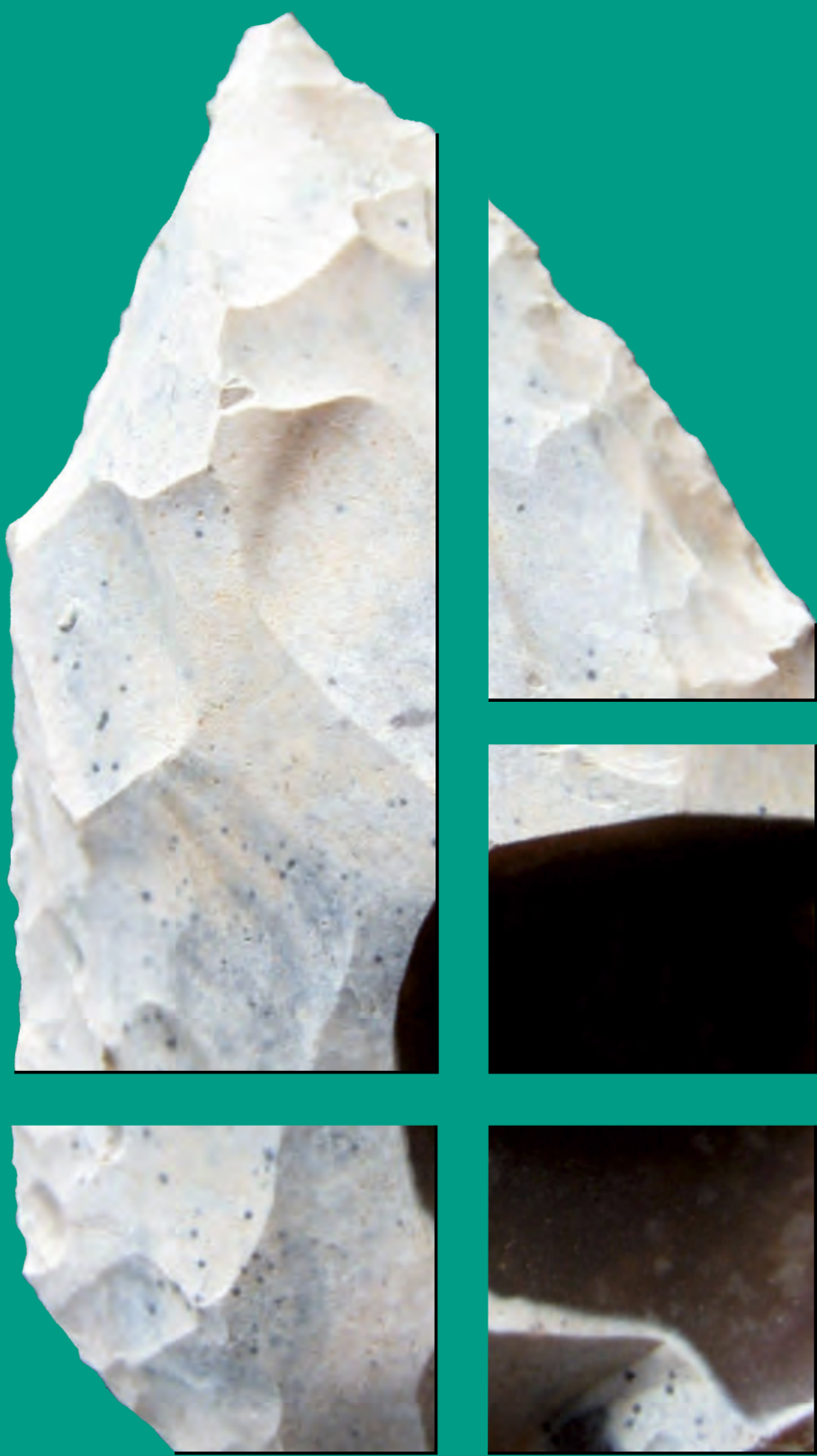

Ser. 3. No.9.| 2021 


\section{Dissertationes Archaeologicae ex Instituto Archaeologico}

Universitatis de Rolando Eötvös nominatae

Ser. 3. No. 9.

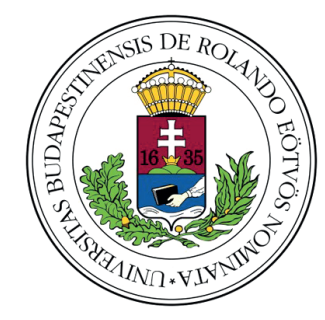

Budapest 2021 


\section{Dissertationes Archaeologicae ex Instituto Archaeologico Universitatis de Rolando Eötvös nominatae}

Ser. 3. No. 9.

Editor-in-chief

Dávid BARTus

Editorial board

László Bartosiewicz (Stockholm University, Stockholm)

Ondřej Chvojкa (University of South Bohemia, České Budějovice)

Zoltán Czajlik (Eötvös Loránd University, Budapest)

Mario Gavranović (Austrian Arhaeological Institute AAS, Vienna)

Hajnalka Herold (University of Exeter, Exeter)

Klára Kuzmová (University of Trnava, Trnava)

Tina Milavec (University of Ljubljana, Ljubljana)

Gábor V. Szabó (Eötvös Loránd University, Budapest)

Tivadar VIDA (Eötvös Loránd University, Budapest)

Technical editor

Gábor VÁcZI

Proofreading

Eszter TímÁr

Strobe DrIVER

Borbála MoHÁcsI

Fruzsina NÉMETH

Eli J. S. WeAVERDYCKE

Aviable online at http://ojs.elte.hu/dissarch

Contact: dissarch@btk.elte.hu

ISSN 2064-4574 (online)

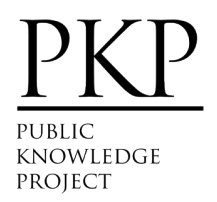

(c ELTE Eötvös Loránd University, Institute of Archaeological Sciences

Layout and cover design: Gábor Váczi

Budapest 2021 


\section{CONTEnTs}

\section{ARTiCles}

Attila PÉNTEK - Norbert FARAgó

Palaeolithic and Mesolithic assemblages from Tunisia

Attila PÉNTEK - Norbert FARAGó

Some remarks on a German chipped stone lithic assemblage of uncertain origin in the collection of the Institue of Archaeological Sciences, Eötvös Loránd University

László Gucsi

Technological observations on a Late Copper Age ceramic assemblage

from Hódmezővásárhely-Kopáncs-Olasz-tanya, Hungary

János Gábor TARBAY

101

A Koszider Period Sword from Tornyospálca-Sírkútgaz (Szabolcs-Szatmár-Bereg County, Hungary)

Ábel GARCZIK

Dolia in the Middle La Tène Period of the Carpathian Basin in the light of new finds from Perkáta-Nyúli-dűlő

Lajos JuHÁsz

An exceptional Sarmatian cast medallion with star and crescent

Gabriella G. DeLBó

New data on the Pannonian glazed casserole handles

Csilla SÁró

The fibula production of Brigetio: Model, semi-finished products, and failed castings

Anita BENES

New data on the capacity of the Roman aqueduct of Brigetio

Melinda SzABó

Status or Role? Differences between the Social Status and Role in Brigetio

Krisztina HoppáL

Roman engraved gems from Southeast Asia 


\section{FiELD REPORTS}

Bence SIMON - Ferenc BARNA

Another barrel-lined well a road section and late Roman graves from Brigetio

Rita RAKONCZAY

Trial excavations in mediaeval churches of Kishartyán, Kisterenye, Mátranovák and Szuha in Nógrád County 2021

\section{Thesis Review Articles}

Tamás KEszi

The change of the pottery style of the Mako and Nagyrév cultures in the Early Bronze Age:

The settlement in Iváncsa-Lapos

Linda Dobosi

Building techniques and building materials in Brigetio:

With the virtual reconstruction of House I/a of the civil town of Brigetio

Csilla SÁRó

Tradition and Romanization by the attire of the Eraviscus tribe 


\title{
An exceptional Sarmatian cast medallion with star and crescent
}

\author{
Lajos JuHÁsz \\ Institute of Archaeological Sciences \\ Eötvös Loránd University \\ juhasz.lajos@btk.elte.hu
}

Received 7 December 2021 | Accepted 19 January 2022 | Published 2 March 2022

\begin{abstract}
An exceptional find of a so-called Sarmatian coin imitation in the form of a lead amulet came to light at Martfü. The obverse is decorated with a bust facing left, the reverse with the usual crescent and star motif. The piece is cast with a loop and an elaborate frame decoration with segmented rims resembling Roman disc fibulae that were popular with the Sarmatians. These types of coins have so far been known only as pierced or looped copper alloy coins primarily from in the Middle Tisza region, although finds outside the Carpathian Basin have also been recently discovered. This new elaborate piece sheds new light on the role and significance of the Sarmatian coin imitations in their society.

Keywords: medallion, Sarmatian, coinage, imitation, amulet
\end{abstract}

The number of metal objects from identified find spots has increased considerably in Jász-NagykunSzolnok County, thanks to the ever-growing number of metal detectorists working with the museums in recent years. The project is headed by Péter F. Kovács of the Damjanich János Museum in Szolnok and András Gulyás of the Jász Múzeum in Jászberény. The number of Roman coins in recent years has grown by several hundred pieces, making a considerable addition to our previous knowledge of this area. ${ }^{1}$ The territory of Jász-Nagykun-Szolnok County has a surprisingly long history of systematic coin collecting thanks to the excellent work of V. Hild published by A. Vaday. ${ }^{2}$ Although the pieces themselves are now dispersed, his detailed descriptions make their identification possible. ${ }^{3}$ Hild primarily collected his material from the Jászság region, near the Devil's Dykes (Csörsz-árok), which explains the large concentration of Roman coins. The most recent metal detectorist activity coordinated by the two local museums supports previously observed tendencies in the Hungarian Barbaricum that show larger amounts of coins in the $2^{\text {nd }} \mathrm{c}$. and under the Constantinian dynasty. However, new data also show higher numbers for the sole reign of Gallienus, the first tetrarchy and the Valentinianic dynasty, previously underrepresented periods. ${ }^{4}$

In September 2020, this knowledge was further augmented by a unique find made by Zoltán Dávid, an active and fortunate member of the team that, due to its rarity and quality, immediately caught everyone's attention. It was discovered at Martfü-Csesz-dülő south of Szolnok, next to the Tisza River, but nothing more is known about its context.

JUHÁsz 2021.

VADAY 1975.

Their reidentification according to the newest catalogues can be found in the Ancient Coins East of the Danube database: http://barbaricoin.elte.hu/AFE_HU/ (last access: 7. 12. 2021).

4 JuHÁsz 2021, 111-112. Further recent finds along the Devil's Dykes are based on I. Steuer's work the results of which he was kind enough to share with me, for which I am grateful to him. 

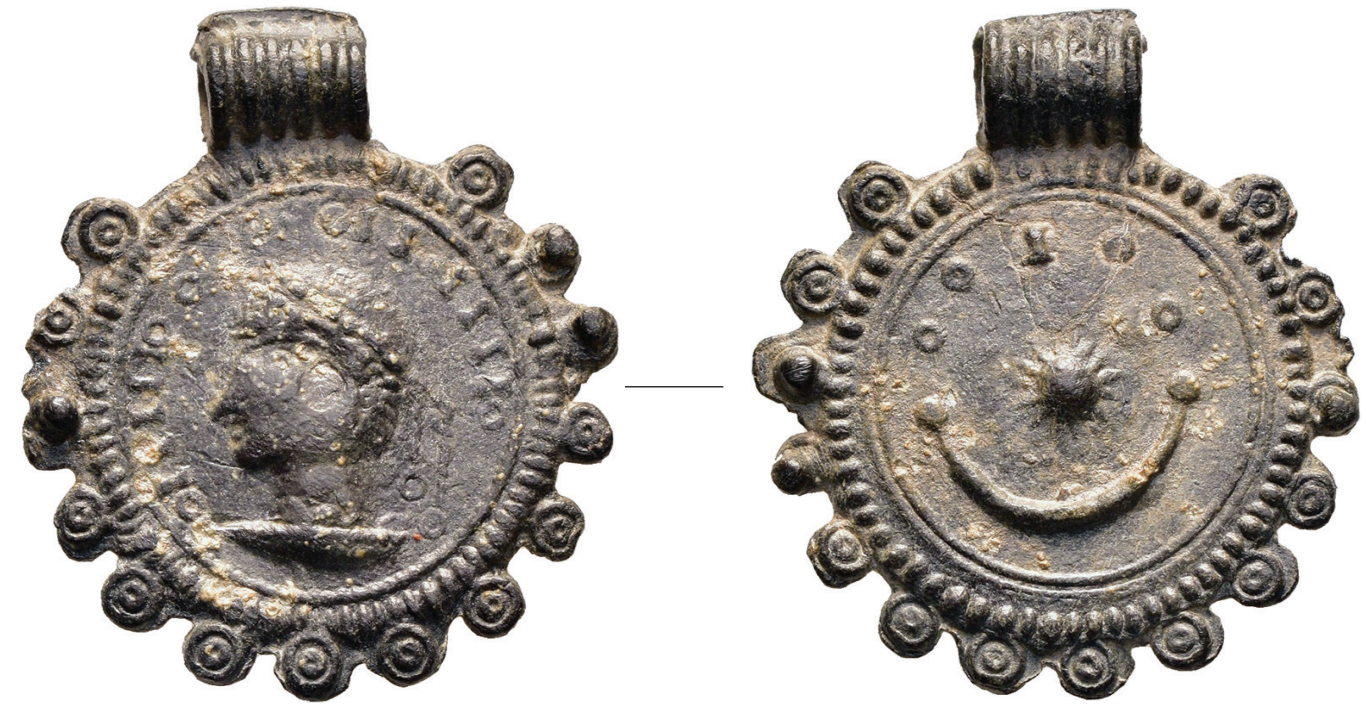

Fig. 1. Sarmatian cast medallion from Martfü-Csesz-dűlő.

The find itself is a medallion measuring $24.46 \mathrm{~mm}$ in diameter with a $3.77 \mathrm{~mm}$ loop at the top and weighing $6.17 \mathrm{~g}$ (Fig. 1). The entire object is cast in one piece and has a decorative frame consisting of three sections. The outer one is made up of 14 concentric circles placed at approximately equal distances, the gaps next to the loop being somewhat bigger. The casting burrs next to the circles are clearly visible. In some cases, at $2 \mathrm{~h}$ and $9 \mathrm{~h}$ the casting deficiencies are presented as small orbs on the circles. The second decorative part is a ribbed band resembling the ones on Roman coins at the edge of the die, which can frequently be seen on coins made into jewellery, where unworn pieces were selected. ${ }^{5}$ This is followed by the innermost plain circle. The obverse itself depicts a bust facing left wearing a diadem, the bands of which are clearly visible behind the head ending in circles. The lower one even shows a small point in the middle just like the concentric circles on the outer decoration of the medallion and the O-s of the legend. The neck ends in a flat torso indicating a draped bust resembling the ones on $2^{\text {nd }}$ and $3^{\text {rd }} \mathrm{c}$. gold and silver coins. The legend consists of unevenly placed I and O letters. The reverse depicts the same mounting, but with two concentric lines next to the ribbed band rather than one. This was made possible by the smaller motif of a star and crescent ending in two dots and the shorter OOIOO legend. The latter is neatly emplaced, continuing in the line of the crescent. The loop consists of six relief bands resembling a spiral with the burr on top.

Unfortunately, the surface is attacked by a yellowish-brown material deteriorating the otherwise nice dark grey medallion. Consulting with conservator-restorer, Emma Sz. Horváth, we initially thought it to be tin pest, although its dark colour indicated a high level of lead. The object was then analysed with an Olympus Vanta handheld EDXRF C series device by Dr. Anna Vihart at the Hungarian University of Fine Arts. The results revealed that it contains $97.47 \%$ lead and $1.64 \%$ phosphorus, all the other impurities ( $\mathrm{Sb}, \mathrm{Fe}, \mathrm{Bi}$ ) being below $0.2 \%$. This led to mixed emotions, since on the one hand, it was obvious that it could not be tin pest, but on the other, the cause of the deterioration was left unaswered.

The medallion's obverse and reverse depiction belong to a group of coin imitations primarily found in the Great Hungarian Plain. These were first identified by Ö. Gohl, who linked them to the Sarmatians based on their find spots and distinctly non-Roman style. ${ }^{6}$ Common for all of them is that

$5 \quad$ E.g. Perassi 2017, Fig. 8,11-12,17,20.

6 Gohl distinguished two groups, the first incorporating the imitations based on various $3^{\text {rd }}$ and $4^{\text {th }} \mathrm{c}$. Roman reverses with legends consisting of the letters I and O. The second group all had the crescent and star reverse. GoHL 1904, 81-86. 

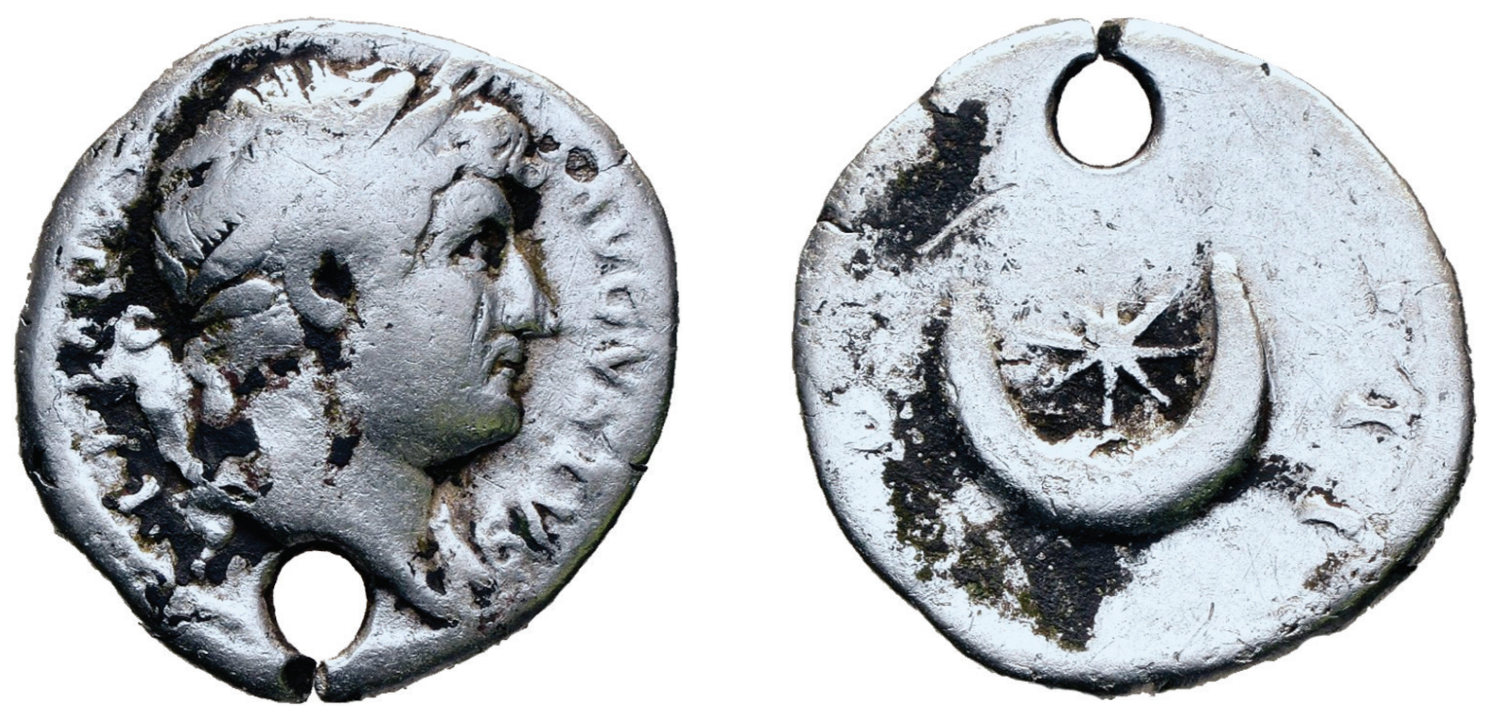

Fig. 2. A pierced coin of Hadrian with star and crescent from the Coin Collection of the Eötvös Loránd University.

they show a portrait on the obverse, usually facing left, while the reverse depicts a crescent and stars. The number and appearance of the stars may vary from simple dots, to dots with rays or a more elaborate, almost floral design. The Sarmatian imitations can be dated to the late Roman period, based on the style and the similarly executed coins that were primarily modelled on $3^{\text {rd }}$ and $4^{\text {th }}$ c. Roman coins. Based on these parallels, the Martfü piece should also be dated to the $4^{\text {th }} \mathrm{c}$. Unlike the lead medallion, the others were all struck of a copper alloy, several of them showing obverse die-links. ${ }^{7}$ They are all pierced or looped, indicating that they were made to be worn. Their style and design also suggest that they were not meant for monetary use, but rather possessed an amulet function. A prime example was discovered in 2017 at Békésszentandrás in a late Sarmatian grave, where the deceased woman wore four of these coins on her forehead as a headdress. ${ }^{8}$ Two other pieces from Mezőtúr-Leski Hill and Zakarpattia Oblast (Ukraine) still had some parts of a bronze chain in the hole. ${ }^{9}$ This leaves no doubt that they were used as amulets, since their common reverse design cannot be a coincidence. The inspiration was taken from Roman coins, namely Hadrian's crescent with the seven stars (septentriones i.e., the constellation of the Plough) reverse first appearing around 127 on denarii symbolising the golden age. ${ }^{10}$ The number of stars later varied, but its symbolic meaning did not change. These were also minted for Sabina and are quite common in the Hungarian Barbaricum, sometimes also worn around the neck (Fig. 2). ${ }^{11}$ This reverse was later repeated by Pescennius Niger and Septimius Severus with AETERNITAS and SAECVLI FELICITAS

7 Unfortunately, material analysis has not been conducted on these coins, but their colour and patina indicate a copper alloy.

8 JuHÁsz 2020.

9 VADAY 1989, 259,203.2; VADAY - HoRvÁTH 2005, 78,24-152; ANOHIN 2015, 205,2.

10 The crescent and star reverses only appear on denarii on imperial coins. The exception to the rule is the aureus, together with a denarius minted by P. Clodius Turrinus (RRC 494/20-21) in 42 BC that in itself is a copy of L. Lucretius Trio's denarius of 76 BC. RRC 390/1. Trio minted the reverse as a pun on his cognomen with the septem trionem i.e. the plough constellation, which is the first appearance of star and crescent on Roman coins (RIC II.3, p. 39).

11 These are also found pierced or looped most recently in late Sarmatian male graves from Üllo and Rákoscsaba (NAGY 2018, 166, Grave 247; JuHÁsz 2020, 140; JuHÁsz 2021, 112). https://www.facebook. com/lelohelyfelderites/photos/a.2256615514596398/2256615614596388 (last access: 01. 11. 2021) A further metal detector find was uncovered with the remains of a loop at Jászágó-Hegyes-halom. This information was brought to my attention by István Steuer, which I am grateful for. 
legends. ${ }^{12}$ The Martfú medallion is based on the crescent with one star reverse, the I and the other four letters $\mathrm{O}$ are merely the legend placed in a decorative manner. ${ }^{13}$

The star and crescent seem to have had a peculiar meaning for the Sarmatians, who presumably did not identify the reverse with the Roman golden age. After all, these are universal symbols readily available to everyone. A special astral connection of the Sarmatians is also expressed by the widespread use of lunulae. ${ }^{14}$ These symbols seem to have been worn by both women and men. The same can be said about the coins with star and crescent reverse: the original looped denarius of Hadrian was found in a male grave around the neck, while the four Sarmatian imitations were placed in a woman's grave at Békésszentandrás. ${ }^{15}$

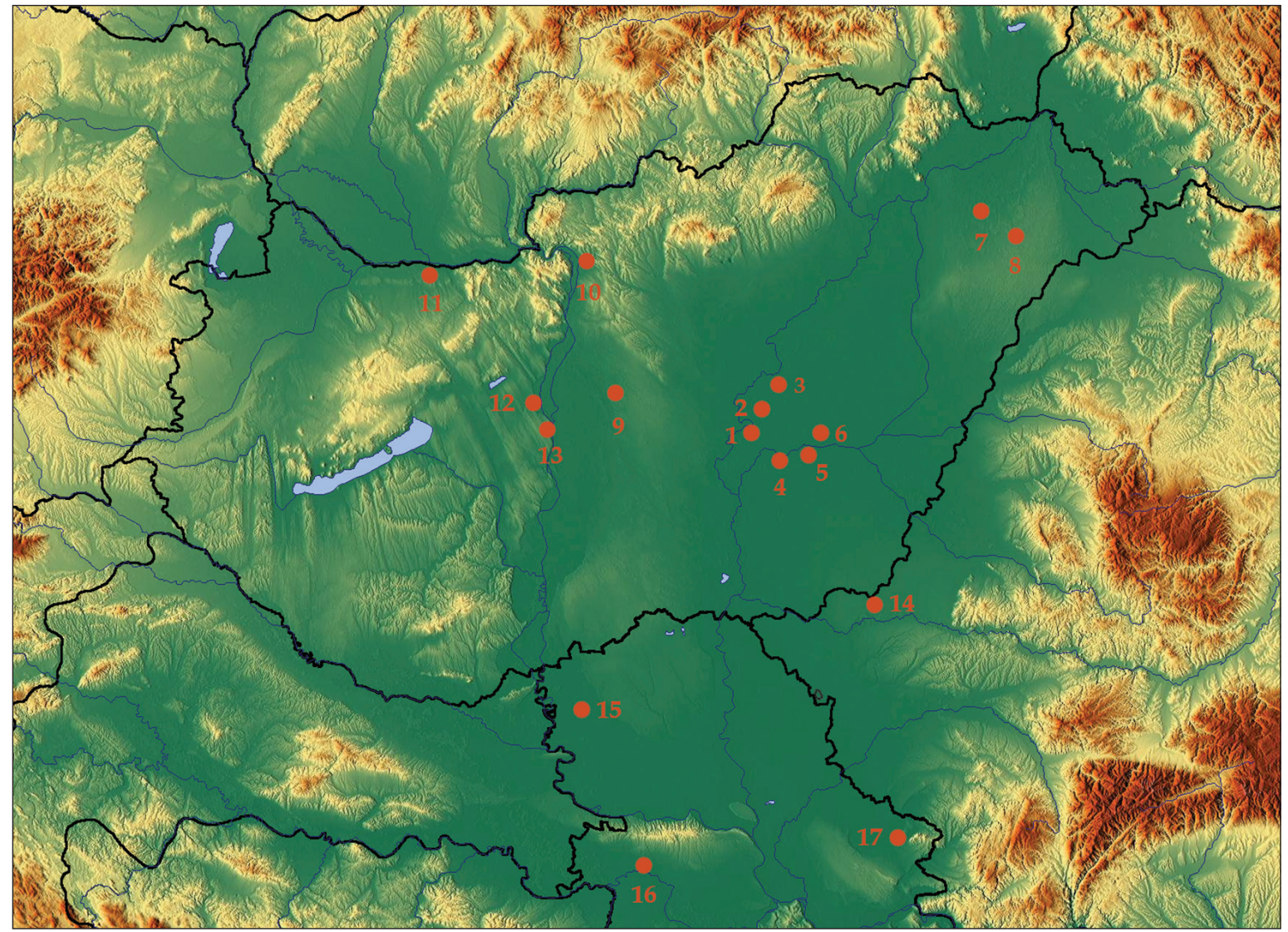

Fig. 3. Sarmatian coin imitations from the Carpathian Basin. 1 - Martfü, 2 - Kengyel, 3 - Törökszentmiklós, 4 - Békésszentandrás, 5 - Szarvas, 6 - Mezőtúr, 7 - Nyíregyháza, 8 - Pócspetri, 9 - Pusztavacs, 10 - Vác, 11 - Brigetio, 12 - Adony/Rácalmás, 13 - Dunaújváros/Intercisa, 14 - Pecica/Pécska, 15 - Sombor/Zombor, 16 - Sremska Mitrovica/Sirmium, 17 - Vršac/Versec.

We do not know whether this lead amulet was worn with the portrait or the astral symbols outward, but based on the Békésszentandrás grave and the Germanic gold coin and medallion analogies, the emperor's head was of greater importance. ${ }^{16}$ Due to the Martfü piece's elaborate frame, it most likely also served a representational purpose besides its apotropaic one. 
Unfortunately, most of the coin imitations with star and crescent reverse are without a find spot. Those that are known show a concentration in the Middle Tisza region (Fig. 3). ${ }^{17}$ Interestingly, some are also found within Pannonia close to the limes at Brigetio, Intercisa and Vetus Salina. ${ }^{18}$ Furthermore, we know of several pieces outside the Carpathian Basin: two from graves in Marten in Bulgaria, two metal detector finds from the Zakarpatska and Volinska Oblast in Ukraine, furthermore some from Central Poland and Moldova. ${ }^{19}$ A similar Sarmatian medallion surrounded by small circles was found at Nyíregyháza, although its state of preservation is significantly poorer. ${ }^{20}$ The other important difference is that this piece is pierced and not looped. These find spots and the elaborate medallion frame indicate a more complex and widespread use of these star and crescent coins than we were previously led to believe.

Inspiration for the elaborate frame could have been taken from the Roman enamelled disc brooches (Scheibenfibel) with protruding circular decoration on the sides, which were popular in the Barbaricum from the $2^{\text {nd }} \mathrm{c}$. to the $260 \mathrm{~s} / 270 \mathrm{~s}^{21}$ These have the same concentric circles on their small projecting round disks as the Martfü medallion (Fig. 4). The flat disc fibulae with segmented rims ${ }^{22}$ show a concentration in the Middle Tisza region similarly to the crescent and star reverse Sarmatian coin imitations. ${ }^{23}$ The other types with similar decoration are the discoidal brooches also very popular in the Barbaricum from the late $2^{\text {nd }}$ to the $5^{\text {th }} \mathrm{c}^{24}$ These more ornate fibulae correspond to the elaborate mounting of the coin imitation. In fact, disc fibulae with

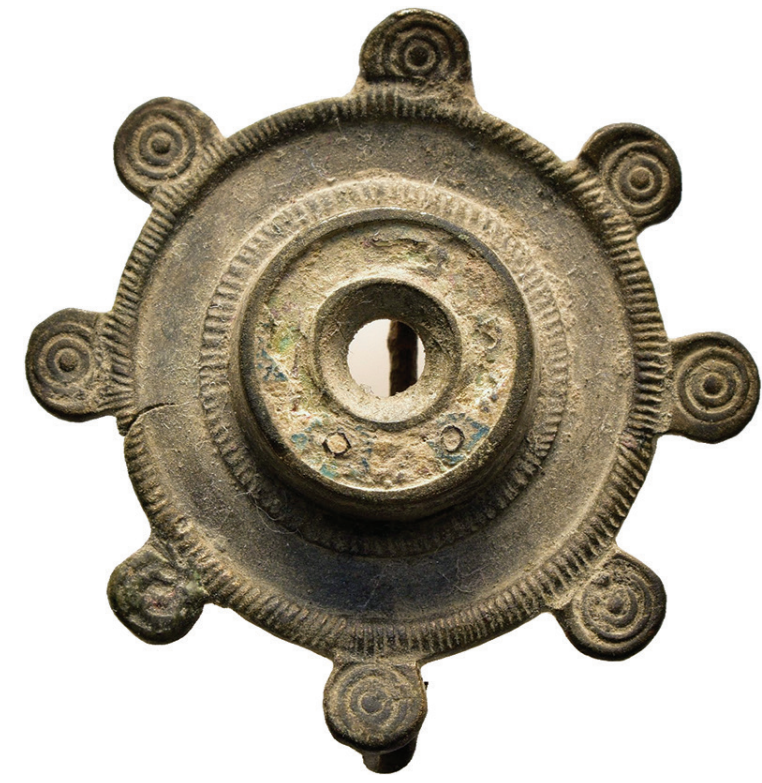

Fig. 4. An enamelled disc fibula with tutulus from a private collection. glass intaglios in the form of human heads are known. ${ }^{25}$ These rare pieces also show a concentration in the central and southern part of the Hungarian Plain in the $3^{\text {rd }}-4^{\text {th }}$ c. A key difference is that the heads are always facing, and the edges of the fibulae are not decorated with projecting round discs, although they are frequently decorated with concentric circles.

The loop on the Martfü medallion is unique among the Sarmatian coins, since it is cast together with the rest of the coin, rather than made by folding the long and narrow excess material over as is usually the case. ${ }^{26}$ As for the pierced pieces, the suspension is not preserved, except for the

17 Three further examples are known from the Koszta József Museum in Szentes, most likely also from the Middle Tisza region (KerÉnYi 1956, 19; JuHÁsz 2021).

18 A further one is in the collection of the Laczkó Dezső Museum Veszprém probably found in northern Pannonia (RHÉ 1905, 67).

19 ANOHin 2015, 205/2, 8.

20 I am indebted for the information to my dear colleague István Vida.

21 VAdAY 1989, 84-85; Grumeza 2015, 195-197, Type IV and VII.

22 VAdAY 2003, Type III/3 and III/5.

23 These brooches were mostly worn by adult woman and girls but were rarely also found in male graves. VADAY 2003, 377.

24 Grumeza 2016, 459.

25 Grumeza 2014, 76-79.

26 E.g., GoHL 1904, 19. ábra. 
two previously mentioned coins with bronze chain and a piece from Marten (Bulgaria), where the loop was made from a separate metal sheet that was fastened with a pin. ${ }^{27}$ Instead the medallion's broad ribbed loop resembles the Sarmatian lunulae, further strengthening the connection between the two types of finds. Similarly, the folding of the excess material to form the loop can also be observed at these crescents. ${ }^{28}$ Occasionally, similar suspension can be seen on gold coins as well. ${ }^{29}$

The Martfü medallion could thus be a rare example of the merger of the production of lunulae, fibulae, and coins. Although the Sarmatian coins were struck copper alloys and not cast lead, it is likely that the two groups of objects may have been produced by the same skilled artisan.

The choice of material is also interesting: lead instead of the usual copper alloy used for coins and fibulae alike. Could this be explained by the simpler production technique or the silvery surface of the lead? Lead amulets in various, also lunula forms are known from Migration period graves worn around the neck as apotropaic amulets. ${ }^{30}$ One should also remember that the material was cheap compared to other metals. This could also imply that the owner could not afford an original Roman denarius with the same depiction, or even a bronze imitation, but was still keen on representing herself or himself with an exceptional piece.

Here we encounter a shift between the various types of objects from a physical form to a representational. The Sarmatian coin imitations copy the form of the lunulae on a coin with no monetary function, but serving as amulets. It seems that this was still regarded as an effective protective measure, maybe even strengthened by the obverse. The role of the imperial portrait is not easy to determine, but its importance is clear. The Martfü cast lead piece is a more elaborate version of this transition between various materials, technical execution and the significance of the crescent and star motif for the Sarmatians. ${ }^{31}$

\section{References}

Anoнin, O. V. 2015: Фальшивомонетчество у варварских племён на территории современной Украины и Молдовы. Каталог варварских подражаний. Dnipropetrosk.

Bursche, A. 2000: Roman gold medallions in Barbaricum. Symbols of power and prestige of Germanic élite in Late Antiquity. In: Klug, B. - Weisser, B. (Hrsg.): XII. Internationaler Numismatischer Kongress Berlin 1997. Akten. Berlin, 758-771.

Bursche, A. 2008: Function of Roman coins in Barbaricum of Later Antiquity. An anthropological essay. In: Brusche, A. - Ciołek, R. - Wolters, R. (eds): Roman coins outside the Empire: ways and phases, contexts and functions. Proceedings of the ESF/SCH Exploratory Workshop, Radziwitt Palace, Nieborów (Poland), 3-6 September 2005. Moneta 82. Wetteren, 395-416.

GoHL, Ò. 1904: Szarmata érmek a római császárság korából. Numizmatikai Közlöny 3, 77-87.

GrumezA, L. 2014: Disc brooches with anthropomorphic depiction glass intaglios in the Sarmatian environment of the Great Hungarian Plain. Journal of Ancient History and Archeology 1:4, 76-84. DOI: 10.14795/j.v1i4.82

27 VARBANOv et al. 2019, 126.

28 E.g., Kőhegyi - Vörös 2011, 271, 282, 303; IstvÁnovits - Kulcsár 2018, 207, Fig. 171; MAstykovA Sviridov 2021, Fig. 13.

29 Bursche 2000, Pl. 2,c,e; Perassi 2017, Fig. 7,10-11,15-16.

30 Grumeza 2021.

31 This research was conducted under the Ancient Coins East of the Danube project (NKFI PD-132300) supported by National Research, Development and Innovation Office. 
GrumezA, L. 2015: Cloisonné Brooches Discovered in Banat (Beginning of the Second Century A.D. - Last Third of the Third Century A.D.). Ziridava - Studia Aechaeologica 29, 191-214.

GrumezA, L. 2016: Sarmatian Personal Ornaments from the South-Eastern Part of the Great Hungarian Plain During the 1st-3rd Centuries CE: Imports and Local Production. In: Cojocaru, V. - Rubel, A. (eds): Mobility in research on the Black Sea region. Cluj-Napoca, 439-482.

GrumezA, L. 2021: Amulete din plumb din a doua jumătate a secolului al V-lea descoperite la Sânpaul (jud. Cluj) (Lead Amulets from the Second half of the $5^{\text {th }}$ Century Discovered in Sânpaul [Cluj Counnty]). Acta Musei Tutovensis 17, 122-134.

Istvánovits, E. - Kulcsár, V. 2018: „...Aligha állhat nekik bármely csatarend ellent.” Egy elfeledett nép, a szarmaták. Nyíregyháza-Szeged.

JuHÁsz, L. 2020: Szarmata érmek fejdíszként egy békésszentandrási késő szarmata női sírból (A Headdress of Sarmatian Coins from a Woman's Grave Dating from the Late Sarmatian Period). Archaeologiai Értesitó 145, 137-143. DOI: 10.1556/0208.2020.00005

JuHÁsz, L. 2021: Újabb antik éremleletek Jász-Nagykun-Szolnok megyéből (Recently Found Antique Coin Finds from Jász-Nagykun-Szolnok County). In: F. Kovács P. - Kelemen A. - Tárnoki J. (eds): Évezredek a Közép-Tisza mentén. Kapcsolatok és hálózatok. Szolnoki Régészeti Tanulmányok 2. Szolnok, 110-123.

KeRÉNYi, A. 1956: Magyarországi szarmata pénzek. Numizmatikai Közlöny 54-55, 14-20.

Kőhegyi, M. - Vörös, G. 2011: Madaras-Halmok. Kr. u. 2-5. századi szarmata temető. Szeged.

Mastykova, A. - Sviridov, A. 2021: The lunula pendants from the cemetery of Frontovoe 3 from the Late Roman Period in the South-Western Crimea. Acta Archaeologica 72:1, 119-136. DOI: 10.1556/072.2021.00007

NAGY, M. 2005: Kora népvándorlás kori gyermeksír amulettekkel Mártélyról (Csongrád megye) (5th century child grave with amulets and iron bell from Mártély [Csongrád Country]). Zalai Múzeum 14, 97-125.

Nagy, M. 2018: A Budapest, XVII. Rákoscsaba, Péceli úti császárkori barbár temető - Das barbarische Gräberfeld Budapest XVII. Bezirk, Rákoscsaba, Péceli Straße aus der jüngeren Kaiserzeit (2-4. Jahrhundert n. Chr.). Budapest.

PerAssi, Cl. 2017: Gioielli monetali romani dai cataloghi d'asta. Un aggiornamento: 2006-2016. Rivista Italiana di Numismatica 118, 227-258.

RIC II.3: Abdy, R. A. - Mittag, P. F.: Roman Imperial Coinage II.3. London, 2019. DOI: 10.2307/j.ctv10qqzjg

RIC IV.1: Mattingly, H. - Sydenham, E. A.: Roman Imperial Coinage IV.1. London, 1936.

RHÉ, Gy. 1905: Szarmata érem a Veszprém-vármegyei múzeumban. Numizmatikai Közlöny 4, 67.

RRC: Crawford, H. M. Roman Republican Coinage. Cambridge, 1974.

VADAY, A. 1975: Szolnok megyei éremtári adatok Hild Viktor jegyzeteiből. Szolnok.

VAdAy, A. 1989: Die sarmatischen Denkmäler des Komitats Szolnok. Ein Beitrag zur Archäologie und Geschichte des sarmatischen Barbaricums. Antaeus 17-18. Budapest, 1-350.

VADAY, A. 2003: Cloisonné brooches in the Sarmatian Barbaricum in the Carpathian Basin. Acta Archaeologica Academiae Scientiarum Hungaricae 54, 315-412. DoI: 10.1556/AArch.54.2003.3-4.2

VAday, A. - HoRváth, F. 2005: Corpus der römischen Funde im europäischen Barbaricum. Ungarn. Band 1. Komitat Szolnok. Bonn.

Varbanov, V. - Dragoev, D. - Rusev, N. 2019: Studied archaeological sites from the Roman period in Rousse region. Rousse. 
